\title{
EXPRESSION OF CAREER SELF-EFFICACY OF STUDENTS ENROLLED IN UNIVERSITY PHYSICAL EDUCATION AND SPORTS STUDY PROGRAMMES
}

\author{
Romualdas Malinauskas, Žilvinas Stankevičius \\ Lithuanian Sports University, Kaunas, Lithuania
}

\begin{abstract}
Research background and hypothesis. An assumption that the fourth-year students of university physical education and sports study programmes have greater career self-efficacy than the first-year students is made in the article.

Research aim was to reveal peculiarities of the expression of the career self-efficacy of the students enrolled in university physical education and sports study programmes.

Research methods. The random sample size consisted of 278 first and fourth-year full time students of physical education and sports study programmes from Lithuanian Sports University and Šiauliai University. Two methods were used to carry out the survey: Career Self-Efficacy Sources Scale (CSESS) and Career Decision-Making SelfEfficacy Scale-Short Form (CDMSE-SF).

Research results. The research showed that there was a statistically significant difference (t $(276)=-1.96$; $\mathrm{p}<0.05$ ) between the first and fourth-year students of university physical education and sports study programmes in respect of the level of career self-efficacy. The fourth-year students were able to make a better use of occupational information $(4.08 \pm 0.54)$ than the first-year students $(3.95 \pm 0.56)$. It was determined that indicators of goal selection and career planning were higher $(\mathrm{p}<0.05)$ in the case of the fourth-year students than in the case of the first-year students.

Discussion and conclusions. It was determined that, in comparison with the first-year students, the career selfefficacy of the fourth-year students of university physical education and sports study programmes was more based $(p<0.05)$ on the following sources: vicarious experience, verbal persuasion and performance accomplishments. Comparison of the levels of career self-efficacy of the first and fourth-year students of university physical education and sports study programmes revealed that the fourth-year students had greater career self-efficacy $(p<0.05)$ and that indicators of the components of their career self-efficacy - occupational information, goal selection and career planning were higher $(\mathrm{p}<0.05)$ than those of the first-year students.
\end{abstract}

Keywords: career education, self-efficacy, career self-efficacy, university studies, physical education and sports.

\section{INTRODUCTION}

$\mathrm{I}$ $\mathrm{n}$ the context of today's globalization and modernization of the society, the situation in the national and regional labour market is changing, skills required to prepare for competition, continuous training and retraining are becoming more relevant. Therefore, education institutions must assume responsibility not only for the general education and training of skilled specialists but also for establishing conditions for acquiring

expertise required for career development systematic and focused career education. At the moment young people in Lithuania with extremely popular university education do not meet the specific professional competence requirements set by employers as a result of too academic and theoretical training. Moreover, there is still a gap to business. In the past career planning was limited only to a situation of choosing a certain profession, 
whereas recently the need for continuous career education during the whole life has increased (Stanišauskienè, Večkienè, 1999; Rosinaite, 2008).

The dynamics of social development and new social-educational conditions require changes in the role of the senior students of physical education and sports study programmes. Sports and sporting activities as a certain feature of a healthy lifestyle here acquire a particular form of expression that generalizes the experience of young people, shapes forms of their thinking and behaviour and defines their future objectives and orientations (Bobrova, 2009). Sports universities begin to carry out a new function - to help students to understand themselves and to strengthen the students' career self-efficacy.

A career is usually defined as a sequence of various socially significant roles of a person which is related to self-expression and individual professional improvement and which reflects a life vision and style of the person (Kučinskienè, 2003; Laužackas, 2005). Self-efficacy is understood as a person's belief in his/her abilities to effectively direct his/her actions to achieve the goals set. Self-efficacy is an individual's expectations or beliefs about how successfully he/she can perform a certain task. In this sense self-efficacy can be considered as a prerequisite for productive and effective activities of an individual (Bandura, 1997). Career self-efficacy plays an important role when analysing career objectives of young people and peculiarities of choosing a career (Bandura et al., 2001; Gianakos, 2001; Turner, Lapan, 2002; Wang et al., 2010). Strengthening career self-efficacy is extremely important for the students of university physical education and sports study programmes as many students who actively go in for sports divide their everyday life into two social environments: academic activities and active training and sports competitions (Bobrova, 2008). This can be called a situation of double socialization (Dencik, 2005). It is a difficult task to perform in two contexts academic studies and sports - because this means a continuous adjustment to each context separately by combining them at the same time, i. e. a student's alternative activity in two fields (even in three in the case of working students) must become an integral academic activity. The ability to perform in two-three social contexts in parallel is the essential requirement for a student who goes in for sports. This model of double socialization forces students to choose landmarks and values for their future career in a very rational way (Bobrova, 2008). Thus, a high level of career self-efficacy is extremely important for the students of university physical education and sports study programmes.

The career self-efficacy indicator helps to determine how an individual will behave in different situations when planning his/her career. High selfefficacy helps to overcome doubts, various troubles and conflicts more easily in difficult situations. Career self-efficacy is one's self-confidence when performing actions related to choosing one's further career (Anderson, Betz, 2001). It is important to analyse career self-efficacy because the analysis of problems related to self-efficacy has shown that this construct can predict professional interests and career objectives and is related to the perceived career opportunities. In addition, it has been determined that career self-efficacy is related to many psychosocial variables, e. g. self-respect, anxiety, inner control focus (Muris, 2002).

A. Bandura (1993) defined four major selfefficacy sources (i. e. performance accomplishments, vicarious experience, verbal persuasion, emotional state). It was determined that selfefficacy could be changed successfully by manipulating the sources of efficiency-related information and performing tasks (McAulley et al., 2001; Malinauskas, Brusokas, 2010; Wang et al., 2010). However, we did not manage to find any papers where the components and sources of career self-efficacy were analysed in a complex manner. Therefore, the question what sources and components of career self-efficacy are typical of the students of university physical education and sports study programmes remains unanswered. The aim of this research was to find out which one of the four self-efficacy sources was emphasized the most by the students of university physical education and sports study programmes. This research is important as it can help understand what motivates the students of university physical education and sports study programmes to look for better career opportunities.

Low career self-efficacy can be based on poor abilities or a lack of personal experience. Awareness of the lack of abilities usually leads to low career self-efficacy which reduces one's willingness to pursue a career (Betz, Hackett, 1981). On the other hand, those who have high career self-efficacy usually have great career ambitions (Bandura, 1993). Persons with high career self-efficacy tend to set more ambitious career goals and objectives 
and to commit to them stronger (Bandura, 1993, 1997).

A level of career self-efficacy can be changed as low career self-efficacy can be increased and high one can be strengthened even more. Furthermore, career self-efficacy is necessary in order to perform successfully and this can affect a person's behaviour irrespectively of the person's knowledge and skills (Bandura, 1993; Chung, 2002). This research is based on a belief that a person with high career self-efficacy will tend to look for such further life's road where he/she could pursue a career. The relevance of the research raises no doubts as there is still a lack of scientific papers on this topic, especially taking into consideration the fact that we failed to find any complex researches into career self-efficacy of students enrolled in university physical education and sports study programmes.

Scientific novelty and originality. This research is new in the sense that, in the absence of detailed researches into career self-efficacy of students of university physical education and sports study programmes, this paper analyses it in a complex manner by including the sources and components of career self-efficacy into the analysis. The problem question of the research is: what are the current characteristics of the expression of career self-efficacy of the first and fourth-year students of university physical education and sports study programmes? The problem question enabled the raising following hypothesis of this research: the fourth-year students of university physical education and sports study programmes have greater career self-efficacy than the first-year students.

Research object - the career self-efficacy of the students enrolled in physical education and sports study programmes.

Research aim was to reveal peculiarities of the expression of the career self-efficacy of the students enrolled in university physical education and sports study programmes.

\section{Research objectives:}

1. To reveal the sources of career self-efficacy of the first and fourth-year students of university physical education and sports study programmes.

2. To assess the level of the components of career self-efficacy of the first and fourth-year students of university physical education and sports study programmes.

\section{RESEARCH METHODS}

Instruments: data collection and analysis. Career Self-Efficacy Sources Scale (CSESS; Anderson, Betz, 2001) was used to assess the sources of career self-efficacy (i.e. performance accomplishments, vicarious experience, positive emotional arousal and negative emotional state). The method consists of 20 statements. Each statement is scored from 1 to 5 . A respondent must choose one the most suitable variants (very often -5 , often 4 , sometimes -3 , very seldom -2 , never -1 ). The scale consists of five sub-scales (4 statements each): performance accomplishments, vicarious experience, verbal persuasion, positive emotional state, negative emotional state. When analysing the data, the average score of each sub-scale which means the indicator of the source of career selfefficacy was calculated. Internal consistency of the method was calculated according to Cronbach's alfa coefficient (0.76) and internal consistency of each sub-scale was also tested. Cronbach's alfa coefficients varied from 0.69 to 0.84 .

Career Decision-Making Self-Efficacy ScaleShort Form consists of 25 statements (CDMSE-SF; Betz et al., 1996). This scale shows peculiarities of a person's self-confidence in performing actions related to choosing his/her further career. The method helps to reveal the following components of career self-efficacy: self-appraisal, occupational information, goal selection, planning and problems solving. Each statement is scored on the Likerttype scale from 1 to 5 . A respondent must choose one the most suitable variant (no confidence at all 1 , very little confidence -2 , moderate confidence 3 , much confidence -4 , complete confidence -5 ). Internal consistency of the questionnaire was calculated according to Cronbach's alfa coefficient (0.64). When analysing the data, the average score collected by each respondent meaning the indicator of career self-efficacy level was calculated. Distribution of the indicator values corresponded to the normal distribution.

Methods of statistical analysis. Internal consistency of the questionnaires used in the research was evaluated according to Cronbach's alfa criterion. Student's t-criterion was used to test statistical hypotheses because the data were distributed according to the normal distribution.

Sample and procedure. Two-stage random selection was used to draw the sample of respondents: first of all, two universities that had 
accredited physical education and sports study programmes were selected from a list of Lithuanian universities on the basis of random number tables. The first and fourth-year full time students of the selected Lithuanian Sports University and Šiauliai University were surveyed. The survey took place in 2012 after agreeing upon with lecturers and obtaining a verbal consent of the respondents. The random sample size consisted of 278 full time students of physical education and sports study programmes as full time studies provide a more solid basis and direction for a student's career designing mechanisms.

When the population size is known, the following formula is used to determine the sample size (Schwarze, 1993):

$n=\frac{N \cdot 1.96^{2} \cdot p \cdot q}{\varepsilon^{2} \cdot(N-1)+1,96^{2} \cdot p \cdot q}$,

where $N$ - the population size; the value 1.96 corresponds to $95 \%$ confidence level of the standard normal distribution; $p$ is the predicted result probability that the analysed attribute will be evident in the surveyed population (usually, the worst scenario probability - the attribute is typical of the half of the population, i. e. $50 \%-$ is taken and then $p=0.5$ ); $q$ is the probability that the analysed attribute will not be evident in the surveyed population $(q=1-\mathrm{p}=0.5) ; \varepsilon$ is the required accuracy, usually $\varepsilon=0.05$. Whereas the population size of the students enrolled in physical education and sports study programmes is approximately $\mathrm{n}=1,000$ persons, hence, the sample size calculated according to this formula is $\mathrm{n}=278$. Therefore, it can be stated that the sample of 278 respondents is a representative one.

\section{RESEARCH RESULTS}

After the sources of career self-efficacy of the first and fourth-year students of university physical education and sports study programmes were analysed and the average scores of the indicators were calculated, it was determined that the fourthyear students were able to make a better use of vicarious experience $(3.31 \pm 0.68)$, whereas the first-year students' vicarious experience, which is gained by observing successful performance of other people (so-called modelling) was poorer $(3.16 \pm 0.59)$. This was also confirmed by the statistically reliable difference received $(\mathrm{t}(276)=-1.99 ; \mathrm{p}<0.05)($ Table 1$)$.

Application of Student's $t$-test revealed that, in comparison with the first-year students, career self-efficacy of the fourth-year students of university physical education and sports study programmes was more based $(\mathrm{p}<0.05)$ on the other following sources: verbal persuasion and performance accomplishments. No statistically reliable difference was found between the career self-efficacy of the first and fourth-year students of university physical culture and sports study programmes in respect of positive and negative emotional arousal $(\mathrm{p}>0.05)$.

The analysis of the survey data revealed that there were no students with low self-efficacy level (from 1 to 2.9 scores) among the fourthyear students of university physical education and sports study programmes. The average career selfefficacy of the first-year students was $3.87 \pm 0.49$ scores, whereas the average career self-efficacy of the fourth-year students was $3.99 \pm 0.53$ scores (Figure).

\begin{tabular}{|l|c|c|c|}
\hline \multicolumn{1}{|c|}{$\begin{array}{c}\text { Sources of career } \\
\text { self-efficacy }\end{array}$} & $\begin{array}{c}\text { First-year students } \\
(\mathbf{n}=\mathbf{1 4 2})\end{array}$ & $\begin{array}{c}\text { Fourth-year } \\
\text { students }(\mathbf{n}=\mathbf{1 3 6})\end{array}$ & $\mathbf{t , p}$ \\
\hline Vicarious experience & $3.16 \pm 0.59$ & $3.31 \pm 0.68$ & $\begin{array}{c}-1.96 \\
\mathrm{p}<0.05\end{array}$ \\
\hline Verbal persuasion & $3.11 \pm 0.69$ & $3.28 \pm 0.73$ & $\begin{array}{c}-1.99 \\
\mathrm{p}<0.05\end{array}$ \\
\hline Positive emotional arousal & $3.26 \pm 0.77$ & $3.29 \pm 0.75$ & $\begin{array}{c}-0.35 \\
\mathrm{p}>0.05\end{array}$ \\
\hline Negative emotional arousal & $2.69 \pm 0.82$ & $2.74 \pm 0.86$ & $\begin{array}{c}-0.50 \\
\mathrm{p}>0.05\end{array}$ \\
\hline Performance accomplishments & $3.69 \pm 0.59$ & $3.84 \pm 0.61$ & $\begin{array}{c}-2.08 \\
\mathrm{p}<0.05\end{array}$ \\
\hline
\end{tabular}

Table 1. Statistical indicators of the career self-efficacy sources of respondents $(\mathrm{M} \pm \mathrm{SD})$

Note. $\mathrm{M}=$ mean; $\mathrm{SD}=$ standard deviation. 
Figure. Mean scores of the level of career selfefficacy among the first and fourth-year students

Note. ${ }^{*}-\mathrm{p}<0.05$.

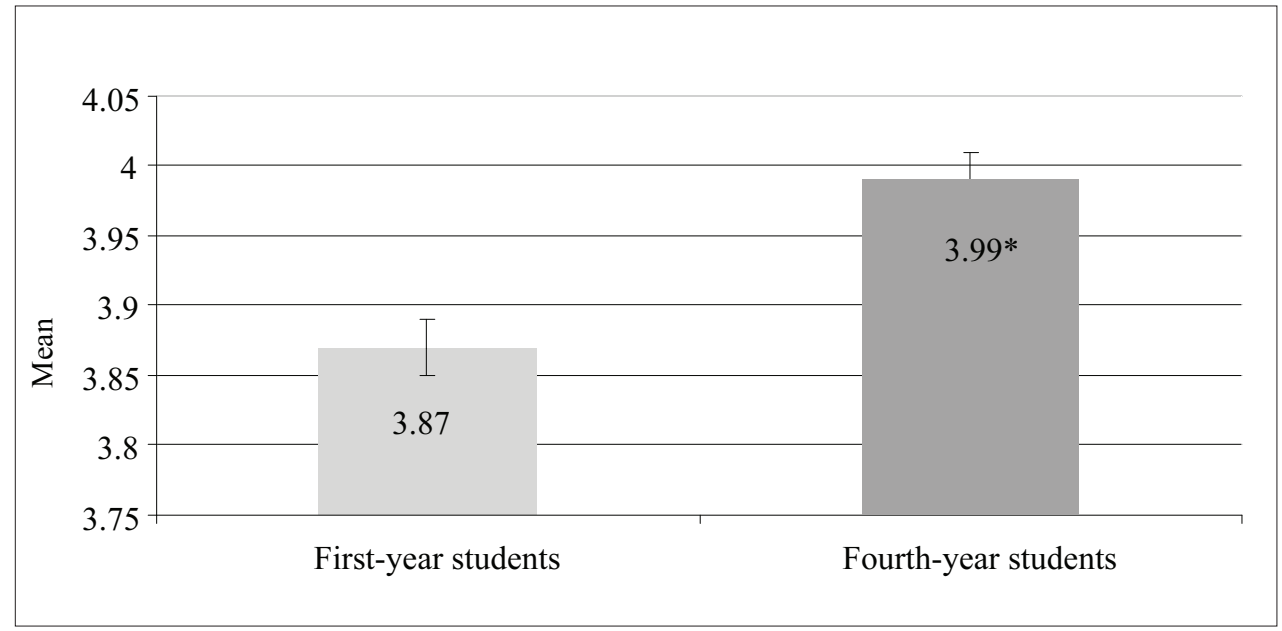

The research showed that there was a statistically reliable difference (t $(276)=-1.96$; $\mathrm{p}<0.05$ ) between the levels of career self-efficacy of the first and fourth-year students of university physical education and sports study programmes.

After the components of career self-efficacy of the first and fourth-year students of university physical education and sports study programmes were analysed and the average scores of the indicators were calculated, it was determined that the fourth-year students were able to make a better use of occupational information $(4.08 \pm 0.54)$ than the first year students $(3.95 \pm 0.56)$. This was also confirmed by a statistically significant difference received $(\mathrm{t}(276)=-1.97 ; \mathrm{p}<0.05)$ (Table 2$)$.

Application of Student's $t$-test revealed that the indicators of goal selection and career planning were higher $(p<0.05)$ in the case of the fourthyear students of university physical education and sports study programmes that in the case of the first-year students.

\section{DISCUSSION}

The hypothesis was confirmed: the fourth-year students of university physical education and sports study programmes had greater career self-efficacy than the first-year students. The results of this research correspond to the data of other researchers confirming that career self-efficacy differs among different study year students (Luzzo, 1993; Creed et al., 2002; Bubany, 2008): senior students have greater career self-efficacy. Just like in the case of other researchers (Iş̧1k, 2010), a conclusion is made that the indicators of the components of career selfefficacy - occupational information, goal selection and career planning - are higher $(\mathrm{p}<0.05)$ in the case of the final-year students than in the case of the first-year students because the former have wider experience and greater expertise. This proves the significance of the data we obtained.

This paper has shown that research into career self-efficacy is a complex process. However, the
Table 2. Statistical indicators of the components of career self-efficacy of respondents $(\mathrm{M} \pm \mathrm{SD})$

Note. $\mathrm{M}=$ mean; $\mathrm{SD}=$ standard deviation.

\begin{tabular}{|l|c|c|c|}
\hline \multicolumn{1}{|c|}{$\begin{array}{c}\text { Components of career } \\
\text { self-efficacy }\end{array}$} & $\begin{array}{c}\text { First-year students } \\
(\mathbf{n}=\mathbf{1 4 2})\end{array}$ & $\begin{array}{c}\text { Fourth-year } \\
\text { students }(\mathbf{n}=\mathbf{1 3 6})\end{array}$ & $\mathbf{t , p}$ \\
\hline Self-appraisal & $3.98 \pm 0.62$ & $3.91 \pm 0.67$ & $\begin{array}{c}0.90 \\
\mathrm{p}>0.05\end{array}$ \\
\hline Occupational information & $3.95 \pm 0.56$ & $4.08 \pm 0.54$ & $\begin{array}{c}-1.97 \\
\mathrm{p}<0.05\end{array}$ \\
\hline Goal selection & $3.92 \pm 0.51$ & $4.05 \pm 0.59$ & $\begin{array}{c}-1.96 \\
\mathrm{p}<0.05\end{array}$ \\
\hline Planning & $3.86 \pm 0.53$ & $3.99 \pm 0.57$ & $\begin{array}{c}-1.97 \\
\mathrm{p}<0.05\end{array}$ \\
\hline Problem solving & $3.57 \pm 0.66$ & $3.61 \pm 0.71$ & $\begin{array}{c}-0.48 \\
\mathrm{p}>0.05\end{array}$ \\
\hline
\end{tabular}


information gathered can help to understand to which sources and components of career selfefficacy the attention should be paid so that the students could be more successful in achieving their career goals. We believe that only complex research that analyses many sources and components of career self-efficacy has practical benefits because conclusions of such research can help choose the most suitable career education models (Jepsen, Dickson, 2003; Taveira, Moreno 2003; Bubany, 2008). We agree with D. Blustein's position (1997) that research into career self-efficacy of students is the most relevant as the respondents of namely this age group make decisions that determine their further career. On the other hand, when the respondents are persons pursuing double career (in our case it is academic and sports career), the experience of such persons enriches research in career education even more.

It can be stated that this research revealed a reliable correlation between the ability to make use of the sources of career self-efficacy demonstrated by the students of university physical education and sports study programmes and career self-efficacy in the youth period. This does not contradict to the data of similar research conducted by other researchers (Foltz, Luzzo, 1998; Dawes et al., 2000). Although other researchers did not study the students engaged in sports activities, the results of their researches are similar to the results of this research. M. Dawes et al. (2000) and P. Creed et al. (2006) found out that low career self-efficacy could limit career development. B. Foltz and D. Luzzo
(1998), M. Thompson and L. Subich (2006) revealed that career self-efficacy could determine a person's behaviour when pursuing a career.To sum up, it can be stated that many variables are analysed during research in career self-efficacy, thus, we believe that such research could include not only the sources of career self-efficacy, level of career selfefficacy and components of career self-efficacy but also search for career opportunities. We believe that it would be useful to continue research in this field and to analyse characteristics of career selfefficacy of students not only of different age but also of different sex who are enrolled in physical education and sports study programmes.

\section{CONCLUSIONS AND PERSPECTIVES}

1. It was determined that, in comparison with the first-year students, career self-efficacy of the fourth-year students of university physical education and sports study programmes was more based $(p<0.05)$ on the following sources: vicarious experience, verbal persuasion and performance accomplishments.

2. The comparison of the levels of career selfefficacy of the first and fourth-year students of university physical education and sports study programmes revealed that the fourth-year students had higher career self-efficacy $(\mathrm{p}<0.05)$ and higher scores $(p<0.05)$ of the components of career selfefficacy - gathering occupational information, selecting career goals and career planning - in comparison with the first-year students.

\section{REFERENCES}

Anderson, S. L., Betz, N. E. (2001). Sources of social self-efficacy expectations: Their measurement and relation to career development. Journal of Vocational Behavior, 58, 98-117.

Bandura, A., Barbaranelli, C., Vittorio Caprara, G., Pastorelli, C. (2001). Self-efficacy beliefs as shapers of children's aspirations and career trajectories. Child Development, 72, 187-207.

Bandura, A. (1993). Perceived self-efficacy in cognitive development and functioning. Educational Psychologist, 28, 117-148.

Bandura, A. (1997). Self-Efficacy: The Exercise of Control. New York: W. H. Freeman.

Betz, N. E., Hackett, G. (1981). The relationship of career related self-efficacy expectations to perceived career options in college women and men. Journal of Counseling Psychology, 28, 399-410.
Betz, N. E., Klein, K., Taylor, K. M. (1996). Evaluation of a short form of the career decision making selfefficacy scale. Journal of Career Assessment, 4, 47-57.

Blustein, D. L. (1997). A context-rich perspective of career exploration across the life roles. Career Development Quarterly, 45, 260-274.

Bobrova, L. (2009). Būsimuju kūno kultūros pedagogų psichosocialinès adaptacijos ypatumai gyvenimo stiliaus kaitos kontekste. Jaunuju mokslininku darbai, 1 (22), 24-32.

Bobrova, L. (2008). Pedagoginio profilio kūno kultūros specialybès studentu gyvenimo stiliaus ugdymas (is) universitetinèse studijose (postmodernios visuomenès iššūkių kontekste). Mokytoju ugdymas, 10, 146-162.

Bubany, S., Krieshok, T., Black, M., McKay, R. (2008). College students' perspective beliefs on their career decision making. Journal of Career Assessment, 16, 177-197. 
Chung, Y. B. (2002). Career decision-making selfefficacy and career commitment: Gender and ethnic differences among college students. Journal of Career Development, 28, 277-284.

Creed, P. A., Patton, W., Watson, M. B. (2002). Crosscultural equivalence of the career decision-making selfefficacy scale - short form: An Australian and South African comparison. Journal of Career Assessment, 10, 327-342.

Creed, P., Patton, W., Prideaux, L. (2006). Causal relationship between career indecision and career decision-making self-efficacy: A longitudinal crosslagged analysis. Journal of Career Development, 33, 47-65.

Dawes, M. E., Horan, J. J., Hackett, G. (2000). Experimental evaluation of self-efficacy treatment on technical/scientific career outcomes. British Journal of Guidance \& Counseling, 28, 87-100.

Dencik, L. (2005). Kaip vaikas isisavina postmoderniojo gyvenimo kokybę. Demokratiškos pedagogikos matai (danu autoriu straipsniu rinkinys kuriančiam mokytojui) (pp. 80-90). Vilnius: Vilniaus kolegija.

Foltz, B. M., Luzzo, D. A. (1998). Increasing the career decision-making self-efficacy with nontraditional college students. Journal of College Counseling, 1, 35-45.

Gianakos, I. (2001). Predictors of career decisionmaking self-efficacy. Journal of Career Assessment, 2, 101-110.

Işık, E. (2010). Career decision self-efficacy among Turkish undergraduate students. Electronic Journal of Research in Educational Psychology, 8 (2), 749-762.

Jepsen, D. A., Dickson, G. L. (2003). Continuity in life-span career development: Career exploration as a precursor to career establishment. Career Development Quarterly, 51, 217-233.

Kučinskienè, R. (2003). Ugdymo karjerai metodologija. Klaipèda: KU.
Laužackas, R. (2005). Profesinio rengimo terminu aiškinamasis žodynas. Kaunas: VDU.

Luzzo, D. A. (1993). Reliability and validity testing of the career decision-making self-efficacy scale. Measurement and Evaluation in Counselling and Development, 26, 137-142.

Malinauskas, R., Brusokas, A. (2010). Savaveiksmiškumo samprata ir sportininkų savaveiksmiškumo ypatumai. Mokslas ir edukaciniai procesai, 4 (13), 68-80.

McAuley, E., Pena, M. M., Jerome, G. (2001). Selfefficacy as a determinant and an outcome of exercise. In G. C. Roberts (Ed.), Advances in Motivation in Sport and Exercise (pp. 235-261). Champaign, IL: Human Kinetics Publishers, Inc.

Muris, P. (2002). Relationships between self-efficacy and symptoms of anxiety disorders and depression in a normal adolescent sample. Personality \& Individual Differences, 32(2), 337-348.

Rosinaitè, V. (2008). Lietuvos aukštujų mokyklų studentų career development kompetencijos: subjektyvus jų isisavinimo lygio ir ugdymo poreikio ivertinimas. Filosofija. Sociologija, 4, 62-71.

Schwarce, J. (1993). Grundlagen der Statistik. Berlin: Neue Wirtschaftsbriefe.

Stanišauskienė, V., Večkienè, N. (1999). Karjeros samprata: mokslinio požiūrio kaita ir jos refleksijos Lietuvoje problema. Socialiniai mokslai, 2 (19), 23-29.

Taveira, M. D., Moreno, M. L. (2003). Guidance theory and practice: The status of career exploration. British Journal of Guidance \& Counseling, 31, 89-208.

Thompson, M., Subich, L. (2006). The relation of social status to the career decision-making process. Journal of Vocational Behavior, 69, 289-301.

Turner, S., Lapan, R. T. (2002). Career self-efficacy and perceptions of parent support in adolescent career development. Career Development Quarterly, 51 (1), 44-55.

Wang, J., Zhang, D., Shao, J. (2010) Group training on the improvement of college students' career decisionmaking self-efficacy. Health, 2, 551-556.

\title{
UNIVERSITETINIŲ KŪNO KULTŪROS IR SPORTO STUDIJŲ PROGRAMŲ STUDENTŲ KARJEROS SAVAVEIKSMIŠKUMO RAIŠKA
}

\author{
Romualdas Malinauskas, Žilvinas Stankevičius \\ Lietuvos sporto universitetas, Kaunas, Lietuva
}

\section{SANTRAUKA}

Tyrimo pagrindimas ir hipoteze. Straipsnyje kelta prielaida, kad universitetinių kūno kultūros ir sporto studiju programų ketvirto kurso studentams būdingas didesnis karjeros savaveiksmiškumas nei pirmo kurso studentams.

Tikslas - atskleisti universitetinių kūno kultūros ir sporto studijų programų studentų karjeros savaveiksmiškumo raiškos ypatumus. 
Metodai. Atsitiktinès imties tūrị sudare 278 kūno kultūros ir sporto studijų programų nuolatinių (dieninių) studiju pirmo ir ketvirto kurso studentai iš Lietuvos sporto universiteto bei Šiaulių universiteto. Apklausos metu pasitelktos dvi metodikos: Karjeros savaveiksmiškumo šaltiniu skale (CSESS) ir Karjeros savaveiksmiškumo komponentu tyrimo skale (CDMSE-SF).

Rezultatai. Tyrimas parodè, kad tarp universitetinių kūno kultūros ir sporto studijų programų pirmo bei ketvirto kurso studentų pagal karjeros savaveiksmiškumo lygi yra statistiškai patikimas skirtumas $(\mathrm{t}(276)=-1,96 ; \mathrm{p}<0,05)$. Ketvirto kurso studentai geba geriau pasinaudoti profesine informacija $(4,08 \pm 0,54)$ nei pirmo kurso studentai $(3,95 \pm 0,56)$. Ketvirto kurso studentu karjeros tikslų užsibrèžimo ir karjeros planavimo rodikliai yra aukštesni $(\mathrm{p}<0,05)$ nei pirmo kurso studentu.

Aptarimas ir išvados. Nustatyta, kad universitetiniu kūno kultūros ir sporto studiju programų ketvirto kurso studentų karjeros savaveiksmiš̌kumas yra labiau $(\mathrm{p}<0,05)$ grindžiamas netiesiogine patirtimi, aplinkinių įikinèjimu ir asmeniniais laimèjimais nei pirmo kurso studentų. Palyginus universitetinių kūno kultūros ir sporto studijų programų pirmo ir ketvirto kurso studentų karjeros savaveiksmiškumo lygi paaiškẻjo, kad ketvirto kurso studentai turi daugiau karjeros savaveiksmiškumo savybiu $(p<0,05)$, jų karjeros savaveiksmiškumo komponentų - profesinès informacijos, karjeros tikslų užsibrèžimo ir karjeros planavimo - rodikliai yra aukštesni $(p<0,05)$ nei pirmo kurso studentur.

Raktažodžiai: ugdymas karjerai, savaveiksmiškumas, karjeros savaveiksmiškumas, universitetinès studijos, kūno kultūra ir sportas.

Gauta 2013 m. sausio 27 d.

Receved on January 27, 2013

Priimta 2013 m. kovo 8 d.

Accepted on March 8, 2013

Corresponding author Romualdas Malinauskas

Lithuanian Sports University

Sporto str. 6, LT-44221 Kaunas

Lithuania

Tel +370 37209050

E-mail romas.malinauskas@1su.1t 